\title{
On the Role of the Microenvironment in Mammary Gland Development and Cancer
}

\author{
Derek Radisky \\ Mayo Clinic Cancer Center, Jacksonville, Florida 32224 \\ Correspondence: Radisky.Derek@mayo.edu
}

B reast cancer can be viewed as a disease of defective development, wherein the processes that guide growth and morphogenesis of the mammary gland are inappropriately activated during tumor proliferation and invasion. Research over the last couple of decades, reviewed by Polyak and Kalluri (2011), has defined some of the key microenvironmental signals that underlie both tissue development and disease progression. Meticulous investigation of animal models has revealed how processes controlling mammary gland development during puberty, pregnancy, lactation, and involution become activated in cancer. For example, some of the same stromally produced matrix metalloproteinases (MMPs) that facilitate outgrowth and branching morphogenesis as the glandular epithelium grows into the fat pad during puberty are also involved in the penetration of the basement membrane by the developing cancer (Wiseman and Werb 2002). In parallel, development of physiologically relevant $3 \mathrm{D}$ culture systems has enabled identification of specific biochemical and biophysical signals, required for maintenance of normal tissue structure, that become dysregulated as tumors grow. For example, recent studies have found that increasing the stiffness and collagen composition of the extracellular matrix can cause normal mammary epithelial structures to acquire invasive characteristics (Egeblad et al. 2010).

Although models for studying the impact of the microenvironment on mammary tissue behavior have become increasingly sophisticated, a significant impediment in elucidating the most important changes in breast cancer development is a limited understanding of the specific microenvironmental cues involved at the earliest stages of disease development. The most commonly hypothesized model of breast cancer development posits an evolution through incremental steps of accumulating cellular abnormalities from normal epithelium through proliferative disease without atypia (PDWA), atypical hyperplasia, ductal carcinoma in situ (DCIS), and then invasive breast cancer (Santen and Mansel 2005). This model is supported by epidemiologic studies that show a stepwise increase in relative risk (RR) of subsequent development of invasive breast cancer from PDWA $(\mathrm{RR}=2)$ to atypical hyperplasia $(\mathrm{RR}=4)$ to DCIS $(R R=10)$ (Arpino et al. 2005). What are the critical factors that influence whether a premalignant lesion will develop into invasive cancer? Although seminal work by Polyak and coworkers (Hu et al. 2005), as well as other researchers, has identified some of the specific characteristics associated with subsequent disease progression for patients with DCIS, such lesions have already accumulated a broad array of genetic and structural abnormalities. Investigations of yet earlier stages of disease may help us

Editors: Mina J. Bissell, Kornelia Polyak, and Jeffrey M. Rosen

Additional Perspectives on The Mammary Gland as an Experimental Model available at www.cshperspectives.org

Copyright (C) 2012 Cold Spring Harbor Laboratory Press; all rights reserved; doi: 10.1101/cshperspect.a013458

Cite this article as Cold Spring Harb Perspect Biol 2012;4:a013458 
D. Radisky

to identify which alterations are the key drivers of progression to malignancy. This information could lead to entirely novel approaches targeting these processes, toward the ultimate goal of prevention of breast cancer formation.

\section{REFERENCES}

* Reference is also in this collection.

Arpino G, Laucirica R, Elledge RM. 2005. Premalignant and in situ breast disease: Biology and clinical implications. Ann Intern Med 143: 446-457.
Egeblad M, Rasch MG, Weaver VM. 2010. Dynamic interplay between the collagen scaffold and tumor evolution. Curr Opin Cell Biol 22: 697-706.

Hu M, Yao J, Cai L, Bachman KE, van den Brûle F, Velculescu V, Polyak K. 2005. Distinct epigenetic changes in the stromal cells of breast cancers. Nat Genet 37: 899-905.

* Polyak K, Kalluri R. 2011. The role of the microenvironment in mammary gland development and cancer. Cold Spring Harb Perspect Biol doi: 10.1101/cshperspect.a003244.

Santen RJ, Mansel R. 2005. Benign breast disorders. N Engl J Med 353: 275-285.

Wiseman BS, Werb Z. 2002. Stromal effects on mammary gland development and breast cancer. Science 296: 10461049. 


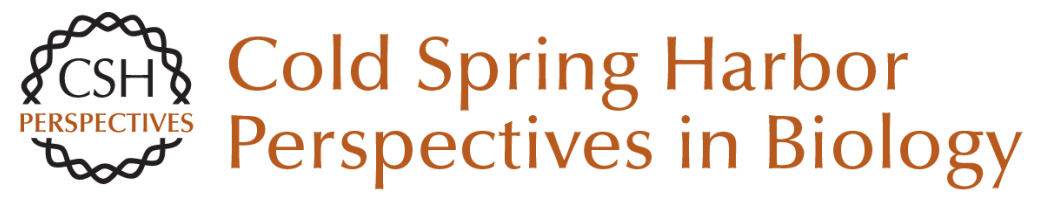

\section{On the Role of the Microenvironment in Mammary Gland Development and Cancer}

Derek Radisky

Cold Spring Harb Perspect Biol 2012; doi: 10.1101/cshperspect.a013458 originally published online May 15, 2012

Subject Collection The Mammary Gland as an Experimental Model

On the Role of the Microenvironment in Mammary

Gland Development and Cancer Derek Radisky

On Using Functional Genetics to Understand

Breast Cancer Biology

Kornelia Polyak

On Oncogenes and Tumor Suppressor Genes in the Mammary Gland

Rushika M. Perera and Nabeel Bardeesy

On Leukocytes in Mammary Development and Cancer

Cyrus M. Ghajar

On Chromatin Remodeling in Mammary Gland

Differentiation and Breast Tumorigenesis Kornelia Polyak

On Hormone Action in the Mammary Gland J.M. Rosen

TGF- $\beta$ Biology in Mammary Development and Breast Cancer

Harold Moses and Mary Helen Barcellos-Hoff
On How Mammary Gland Reprogramming

Metalloproteinases Couple Form with Function Bonnie F. Sloane

On Molecular Mechanisms Guiding Embryonic

Mammary Gland Development

Gertraud W. Robinson

On Stem Cells in the Human Breast Mark A. LaBarge

On Murine Mammary Epithelial Stem Cells:

Discovery, Function, and Current Status Jeffrey M. Rosen

On In Vivo Imaging in Cancer David Piwnica-Worms

Choosing a Mouse Model: Experimental Biology in Context--The Utility and Limitations of Mouse Models of Breast Cancer Alexander D. Borowsky

Mammary Gland ECM Remodeling, Stiffness, and Mechanosignaling in Normal Development and Tumor Progression Pepper Schedin and Patricia J. Keely

For additional articles in this collection, see http://cshperspectives.cshlp.org/cgi/collection/

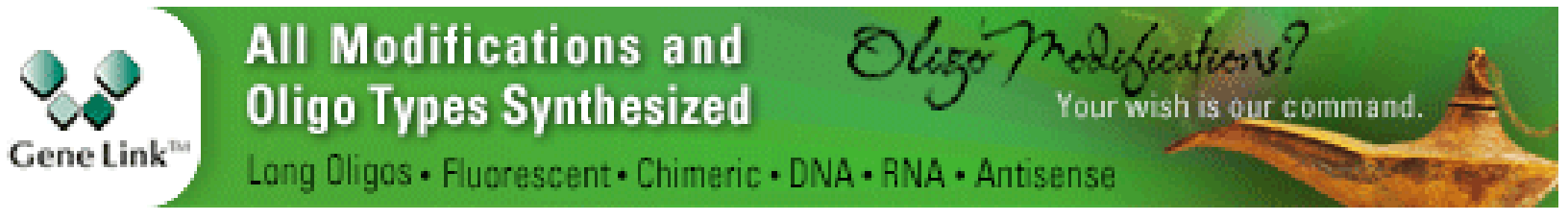


A Compendium of the Mouse Mammary Tumor Biologist: From the Initial Observations in the House Mouse to the Development of Genetically Engineered Mice

Robert D. Cardiff and Nicholas Kenney
Molecular Mechanisms Guiding Embryonic Mammary Gland Development

Pamela Cowin and John Wysolmerski

For additional articles in this collection, see http://cshperspectives.cshlp.org/cgi/collection/

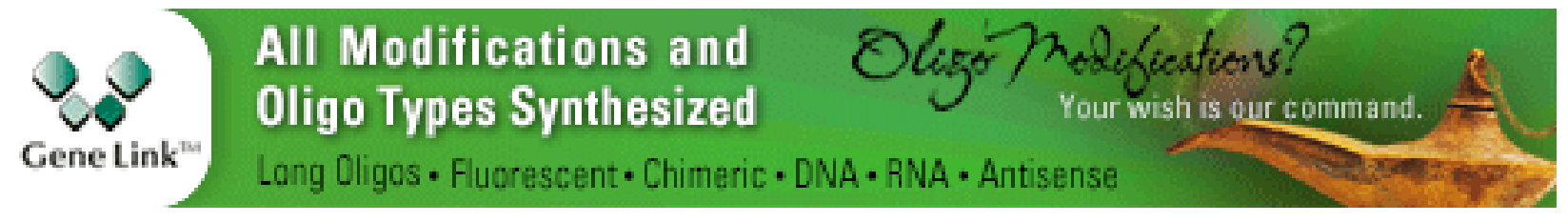

Copyright @ 2012 Cold Spring Harbor Laboratory Press; all rights reserved 